University of Rhode Island

DigitalCommons@URI

Open Access Master's Theses

2000

\title{
A Study of Language Used in Magazine Reports of Rape and Sexual Assault Trials
}

Laura B. Chorbajian

University of Rhode Island

Follow this and additional works at: https://digitalcommons.uri.edu/theses

\section{Recommended Citation}

Chorbajian, Laura B., "A Study of Language Used in Magazine Reports of Rape and Sexual Assault Trials" (2000). Open Access Master's Theses. Paper 1617.

https://digitalcommons.uri.edu/theses/1617

This Thesis is brought to you for free and open access by DigitalCommons@URI. It has been accepted for inclusion in Open Access Master's Theses by an authorized administrator of DigitalCommons@URI. For more information, please contact digitalcommons-group@uri.edu. 
A STUDY OF LANGUAGE USED IN MAGAZINE REPORTS OF RAPE AND SEXUAL ASSAULT TRIALS

BY

LAURA B. CHORBAJIAN

A THESIS SUBMITTEED IN PARTIAL FULFILLMENT OF THE REQUIREMENTS FOR THE DEGREE OF MASTER OF ARTS

IN PSYCHOLOGY

UNIVERSITY OF RHODE ISLAND 2000 


\begin{abstract}
The purpose of this study was to examine the descriptors used to describe victims and alleged perpetrators in recent articles about rape trials and sexual assault trials in popular U.S. magazines to determine whether they were significantly different in connotative meaning as perceived by the respondents. Forty-four articles were examined for descriptors. The ten most commonly used descriptors for the victims and the ten most commonly used descriptors for the alleged perpetrators were then rated on Osgood's semantic differential by 107 undergraduates from the University of Rhode Island. Results showed that descriptors for the victims and alleged perpetrators were found to be significantly different on the three semantic factors of evaluation, potency, and activity. Descriptors used to describe the victims were judged as connoting less favorability, less potency, and less activity than those used to describe the alleged perpetrators. These words may affect the way in which victims and perpetrators are perceived by their readers.
\end{abstract}




\section{Acknowledgment}

The author wishes to express her sincere appreciation to Dr. Bernice Lott for her guidance, encouragement, and immense patience throughout the course of this study.

Thanks are also expressed for the assistance given by committee Professors Larry

Grebstein, Barbara Luebke, and Mary Ellen Reilly. 


\section{Table of Contents}

List of Tables........................................................................

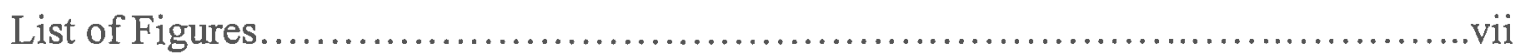

Statement of the Problem..........................................................

Literature Review...............................................................

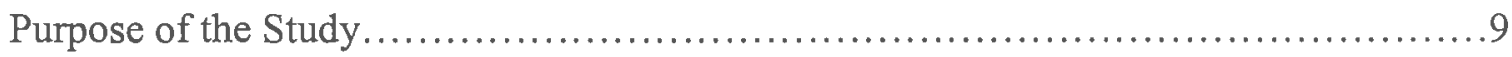

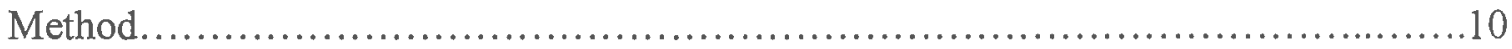

Part I...........................................................................

Sample.......................................................... 10

Procedure.......................................................... 10

Instruments..................................................... 11

Analysis.........................................................11

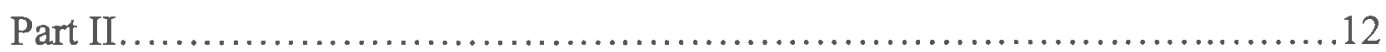

Participants.......................................................... 12

Procedure.......................................................... 12

Instrument..........................................................

Analyses......................................................... 14

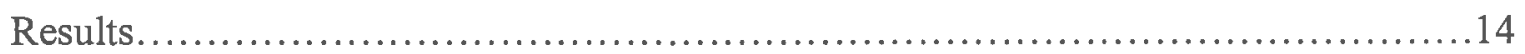

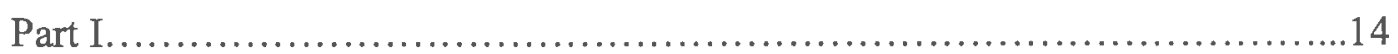

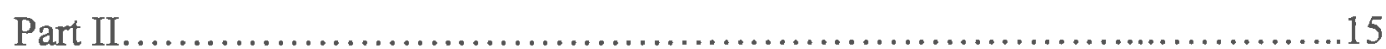

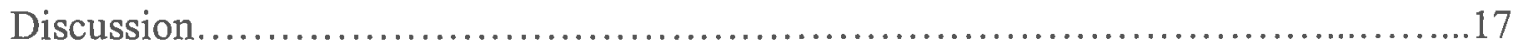

References................................................................... 21

Appendix A. Articles............................................................ 24 


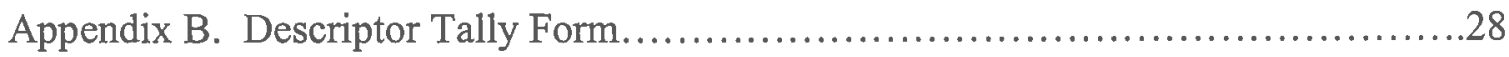

Appendix C. Informed Consent and Instructions for Semantic Differential..............30

Appendix D. Demographic Information........................................... 34

Appendix E. Semantic Differential Scales...................................... 35

Appendix F. Debriefing Statement............................................. 36

Appendix G. Most Frequently Used Descriptors.................................37

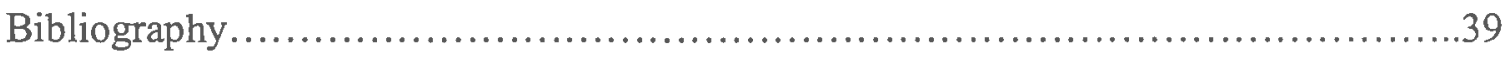


List of Tables

Table I. Most Commonly Used Descriptors for Victims and Alleged Perpetrators....15 


\section{List of Figures}

Figure I. Mean ratings for descriptors on the three semantic factors ..................17 


\section{Statement of the Problem}

Rape is a violent crime. Estimated rape victimization rates of both attempted and completed rapes in 1998 by the National Crime Victimization Survey (NCVS) were 0.9 per 1,000 persons age 12 and over. Koss (1992), in reference to the National Crime Survey estimates of 1989, argued that rape incidence might be 6-10 times higher than NCS estimates. Prevalence studies indicate that $15-20 \%$ of women have been raped at some point in their lives (Koss, Gidycz \& Wisniewski, 1987). While men, too, can be raped, the present discussion is focused on the sexual assault of women, the primary victims. The victim of rape often becomes the target of blame and is held accountable for her victimization. In addition to symptoms that represent the immediate traumatic response to rape, the victim often suffers long-term negative consequences. "The core features of these long-term symptom patterns appear to be a set of fear/avoidance responses, affective constriction, disturbances of self-esteem/self-efficacy, and sexual dysfunction" (Koss \& Burkhart, 1989, p. 29).

Beliefs and attitudes about rape provide the framework through which our judgments, perceptions, interpretations, and responses to rape victims are filtered. These beliefs are both affected by and reflected in rape myths. One function these myths serve is to distance "us", the non-victims, from those who have been victimized. Myths and beliefs that she, the victim, provoked her assault, or she deserved it, that only "loose women" are raped or that she is "spoiled" or "dirtied" by the rape, make her, the victim, different from "me". The destructive consequences of these beliefs for the victim of rape 
and for the public understanding of rape are many. In addition to blaming the victim, we tend to place the victim in an "outgroup", both marginalizing and stigmatizing her.

The myth that rape is sex denies that the victim was hurt, as well as the seriousness of the assault. Blaming the victim and denying that the victim was hurt reduce our capacity to empathize, and thus further distances us from the victim. Rape is a violent act and "one of the most traumatic events that can happen to a person" (Benedict, 1992, p. 14). Blaming the victim often results in lowering her self-esteem and evoking feelings of guilt, shame, isolation, and/or depression. Just as age, ethnicity, socioeconomic class, and gender are aspects/elements of one's identity, so, too, the experience of having been raped may become part of one's identity.

Rape and other forms of sexual assault have become regular topics in the news media in the form of news stories as well as features, columns, and even first person accounts. Because of the nature of news media reports there is little discourse about the sociocultural or historical context of rape. And there is little recognition that "rape is a crime of opportunity" and "any female may become a victim of rape" (Brownmiller, 1975, pp. 349 and 348). Renzetti and Curran (1999) point out that the mass media do more than just passively reflect culture; they actively shape and create it. The mass media may thus serve to reinforce and even shape our attitudes and beliefs about rape as they do with other topics. "The modern mass media are a significant force - and perhaps the most significant force - influencing each of our lives... it is likely that the scope and significance of this influence has now surpassed that of all other social institutions, including religion and government" (Kielwasser \& Wolf, 1994, p. 61). 
The goal of the present study was to explore representations of rape and sexual assault in popular magazines. Popular magazines were chosen because they have both a wide and national readership. This study looked specifically at the descriptors (adjectives, adverbs and words used as adjectives or adverbs) used in connection with victims and alleged perpetrators of rape and sexual assault. The research question pursued in this study was whether the descriptive words used for victims and alleged perpetrators differed in connotative meaning in the direction of supporting rape myths.

\section{Literature Review}

"To a woman the definition of rape is fairly simple. A sexual invasion of the body by force, an incursion into the private, personal inner space without consent - in short, an internal assault from one of several avenues and by one of several methods constitutes a deliberate violation of emotional, physical and rational integrity and is a hostile, degrading act of violence that deserves the name of rape" (Brownmiller, 1975, p. 376). Yet, definitions of rape vary widely. At one time, for example, the sexual assault of a virgin had more serious consequences because it spoiled the victim's purity. Definitions of rape are socially and culturally constructed. (See Brownmiller, 1975, and Donat and D'Emilio, 1992, for changes in the meanings of sexual assault.) Definitions of rape affect whether the same behavior will be labeled "rape" by victims, perpetrators, and the social and legal communities (White \& Sorenson, 1992). The generally accepted definition of rape or sexual assault is the nonconsensual penetration of an adolescent or adult by physical force, by threat of bodily harm, or when the victim is incapable of giving consent by virtue of mental illness, mental retardation, or intoxication (Koss, 1992). "Such a definition is found in the legal statutes of all states, all of which treat rape 
as a violent crime, a felony, punishable under the law. Because forced sexual acts may involve penetration of various body parts or other acts of a broadly sexual nature, and because attempted rape is sometimes successfully thwarted, some state laws now refer to forced sexual acts as sexual assault rather than rape" (Lott, 1994).

Rape does not exist in all cultures. "Social ideologies, not human nature, prepare men to abuse women" (Sanday, 1990, p. 192). In a review of anthropological data from 156 tribal societies, Sanday (1981) found many that were rape free. To fully understand rape we must look at its sociocultural and historical context. "Rape is both a tool and consequence of an interlocking system of oppressions... Institutionalized differences in power influence who can rape whom and get away with it, and what happens to the rape victim in the aftermath of the rape" (Holzman, 1994, p. 83). In addition, as noted by Wyatt (1992, p. 77), "the effects of sexual victimization can be influenced by perceptions of the experience, attributions of blame, and expectations of how victims will be judged by those around them." Factors that determine power and status in the majority culture, such as ethnicity, socioeconomic class, sexual orientation, and religious beliefs are especially important (Holzman, 1994).

Brownmiller (1975, p. 389) has argued that "the ideology of rape is fueled by cultural values that are perpetuated at every level of our society." Rape myths are prejudicial, stereotyped, and false beliefs about rape, rape victims, and rapists (Burt, 1980) and are not consistent with one another. Examples of rape myths include: 1) rape is just sex; 2) the assailant is motivated by lust; 3) the assailant is perverted or crazy; 4) the assailant is usually Black or poor; 5) the woman provoked the rape; 6) the woman deserved to be raped; 7) only "loose" women are victimized; 8) a sexual attack sullies the 
victim; 9) rape is a punishment for past deeds; and 10) women cry rape for revenge (Benedict, 1992). Rape myths are pervasive and serve to reinforce the dominant social structure. They serve as a mechanism for maintaining male control and domination, reinforcing women's subordination to men. Rape myths are part of the ideology that supports or excuses sexual assault (see: Brinson, 1992; Brownmiller, 1975; Burt, 1980; Myers, 1994; Weis \& Borges, 1973). Research by Burt and Albin (1981) found that rape myth acceptance had a direct effect on rape definitions, where the greater the rape myth acceptance, the narrower the definition of rape. "[A]cceptance of rape myths leads to more restrictive definitions and is thus rape-supportive because it denies the reality of many actual rapes" (Burt \& Albin, 1981, p. 213).

In addition to the physical pain experienced by victims of sexually assaultive behaviors, many victims also suffer from embarrassment and confusion about responsibility for their victimization and may feel isolation and shame. Cultural beliefs have taught some women to blame themselves (Lott, 1994). Many women who have been victimized do not even acknowledge it. In a study by Reilly et al. (1992), only $43 \%$ of a sample of college women in a highly victimized category acknowledged that they had been raped.

Rape survivors are often blamed by others for their assault and accused of inviting or deserving the attack. Rape myths blame the victim for somehow inviting the rape. Blaming the victim reduces our capacity to empathize, and thus results in a distancing of us from the victim. Meyers (1994), in a textual analysis of the newspaper coverage of the murder of a battered woman by her husband, showed how myths and stereotypes 
combined to blame the victim for her own death. Blaming the victim is a primary barrier to social change because it diverts attention from the perpetrator (Meyers, 1994).

Brinston (1992) examined the pervasiveness of rape myths in prime-time television dramas and suggested that television programs are vehicles through which cultural values and attitudes are absorbed and distributed. "The overuse of rape myths in prime-time television dramas reinforces the belief women are responsible for the rape, not men. Their use also appeals to cultural attitudes rooted in patriarchy. They reinforce the belief that specific behaviors are expected of women, and the failure of women to conform to these expectations results in the 'just' punishment of rape. They strengthen the perception of rape as essentially sexual in nature" (p. 373).

The news media both reflect and shape public opinion. "Sometimes, by reporting events and echoing what is said out in the field, it merely reinforces established opinions by mirroring them. At other times it takes a more active role, suggesting new views and challenging old ones... When the press reports a sex crime... it is also reflecting the public opinions elicited by that crime" (Benedict, 1992, pp. 3-4).

There is a large body of empirical research linking attitudes to exposure to film and TV media. Empirical research has consistently shown a relationship between continual exposure to media violence against women and a desensitization and callousness toward female victims of violence, especially rape. In a study of college-age men, Linz, Donnerstein, and Penrod (1984) measured reactions to films portraying violence against women over a five day period and found that material that was initially judged as violent and degrading to women was judged significantly less so after five days of exposure. Mullin and Linz (1995) found that three days after viewing sexually violent 
films "experimental participants expressed significantly less sympathy for domestic violence victims, and rated their injuries as less severe, than did a no-exposure comparison group" (p. 449). After reviewing desensitization work by Bandura (1969), Proctor (1968), Wolpe and Lazarus (1966), Wilson and Davison (1971), and Eysenck (1963), Cline, Croft, and Carrier (1973) suggested that exposure to a great deal of violence either directly or vicariously (newspapers, television and other media) may result in a "tuning out" of normal emotional responses to violent acts. Cline, Croft, and Carrier found that children with histories of high-television-exposure were significantly less aroused autonomically when they were exposed to a moderately violent film than other children, suggesting measurable desensitization to filmed violence.

In a study that examined the effects on male viewers of prolonged exposure to three types of depictions of women in films, Linz, Donnerstein, and Penrod (1988) found that prolonged exposure to sexually violent material desensitized people. For example, "(s)exually violent material that was originally anxiety provoking and depressing became less so with prolonged exposure, ... (s)ubjects exposed to the sexually degrading R- and $\mathrm{X}$-rated films reported seeing less violence with continued exposure, $\ldots$ films once found degrading to women were judged to be less so after prolonged exposure" (pp. 765-767). Study participants were less able to empathize with rape victims in general as well as in a specific rape trial. No new work on desensitization and media has been done in the past decade.

Soothill (1991) noted that in Britain a disproportionate amount of print media coverage is given to multiple rapes by one offender or gang rapes, leading to the possibility that "the more prevalent activity of one man having or attempting intercourse 
with one woman without her consent will implicitly be taken less seriously, particularly when the man and the woman are already known to each other" (p. 384). Soothill compared print media coverage of rape trials with information provided by the courts of rape cases between the early 1970s and mid-1980s and found that the two profiles were not converging but diverging. The print media's presentation of rape "suggests that rape is primarily about sexual attacks in public places by strangers and/or gangs" (p. 391), which is counter to the facts about rape. He found that a disproportionate amount of print media attention was given to serial rapists in particular, the least likely to actually occur.

In Benedict's (1992) empirical examination of how the press dealt with four specific sex-crime cases, she notes that their portrayal of female crime victims is shaped by their language and rape myths. "The press habitually uses words to describe female crime victims, especially sex crime victims, that are virtually never used for men. Those words are consistently sexual, condescending, or infantilizing... Men are never described as hysterical, bubbly, pretty, pert, prudish, vivacious, or flirtatious, yet these are all words used to describe female victims..." (p. 20). While these are adjectives that may generally be used to describe women in a variety of circumstances, Benedict claims that "a sex crime victim tends to be squeezed into one of two images - she is either pure and innocent, a true victim attacked by monsters... or she is a wanton female who provoked the assailant with her sexuality..." (p. 18).

Foreit and her colleagues (1980) "found that in female-centered news stories, reporters were likely to mention an individual's sex (e.g., "the female attorney"), physical appearance (e.g., "the petite blond"), and marital status or parenthood (e.g., "Dr. Smith is 
the wife of" or "the feisty grandmother"). Such details were rarely provided in malecentered stories" (cf. Renzetti \& Curran, 1999).

\section{Purpose of the Study}

Because the mass media are such a significant force influencing our lives and because the print media are the subject of research less often than television (Renzetti \& Curran, 1999), this study examined articles about rape trials and sexual assault trials in popular U.S. magazines. Popular magazines were chosen because they have both a wide and national readership. Magazines, unlike local newspapers, are read across the U.S. and thus, they have the potential to reach and influence a larger number of people and a more diverse group of people. The language used to describe victims and alleged perpetrators was examined in order to see if the language might tend to perpetuate rape myths and reduce the readers' empathy for the victim. This study examined the descriptors (adjectives, adverbs and words used as adjectives or adverbs) used to describe the victims (and their behavior) and the descriptors used to describe the alleged perpetrators to determine whether they were significantly different in connotative meaning as perceived by respondents. It was hypothesized that these descriptors would be significantly different on three semantic factors: evaluation, potency, and activity. Descriptors used to describe the victims were predicted to be ones that would be judged as connoting less favorability, less potency, and less activity than those used to describe the alleged perpetrators. 


\section{Method}

\section{$\underline{\text { Part I }}$}

The first part of this study involved the recording and tallying of descriptors (adjectives, adverbs and words used as adjectives or adverbs) used to describe victims and alleged perpetrators in a sample of popular U.S. magazine articles about rape trials and sexual assault trials.

Sample. The sample consisted of 44 recent articles (see Appendix A) about rape trials and/or sexual assault trials (as indexed by the Reader's Guide to Periodical Literature) appearing between January 1990 and December 1999 in U.S. news-weeklies as classified by SRDS Consumer Magazine Advertising Source (July 1999). The U.S. news-weeklies that had articles about rape trials and/or sexual assault trials that were included in this study were: Jet, Newsweek, People weekly, Sports Illustrated, Time, and U.S. News \& World Report. The investigator selected from a larger pool of 63 articles only those which discussed a female victim and/or an alleged male perpetrator of a rape or sexual assault crime. Articles covering the much-publicized Bobbitt case were not included since Lorena and John Bobbitt were each sometimes described as the victim and at other times as the alleged perpetrator.

Procedure. The researcher read each article, wrote a brief summary of the article, and listed and tallied all descriptors (adjectives, adverbs and words used as adjectives or adverbs) used in connection with the victim(s) and the alleged perpetrator(s).

Descriptors inside a quote were noted by putting quotation marks around those descriptors. The researcher's major professor read every article to arrive at consensus. Phrases sometimes complicated the identification of descriptors. Some troublesome 
examples included "beyond evil or humanity", "member of in crowd", "serial buttocks fondler", "all-American girl”, "compelling desire for money", and "predatory seductress". These were discussed and their inclusion/exclusion was ratified by mutual agreement. The 10 most commonly used descriptors for victims and the 10 most commonly used descriptors for alleged perpetrators were determined by grouping descriptors with similar meanings, using one of the descriptors to represent the group. While the selection of a descriptor to represent a group was a judgment call, three criteria helped the researcher and her major professor to make this decision. When a descriptor was used more frequently than the other descriptors in the group it was selected to represent the group. Single word descriptors were chosen over phrases. And finally, descriptors were chosen that were thought to be familiar to undergraduates. It was necessary to identify the descriptors used most frequently in order to test for differences in connotative meaning between those used for victims and those used for perpetrators by presenting a limited number of descriptors for ratings by a group of respondents.

Instruments. A record form (see Appendix B) was used for each article to tally all descriptors used in connection with the victim and/or alleged perpetrator. In the event that there were two or more victims and/or alleged perpetrators in a given article, the descriptors for all the victims and/or alleged perpetrators were tallied together.

Analysis. The mean number of times each descriptor was used in connection with victims and alleged perpetrators was calculated. The 10 most frequently used descriptors for each group were further analyzed in Part II of the study. 


\section{$\underline{\text { Part II }}$}

The second part of this study compared the connotative meanings of the frequent descriptors for victims and alleged perpetrators that were identified in Part I.

Participants. A convenience sample of 107 college students, recruited (with the permission of their professors) from psychology classes at the University of Rhode Island, were asked to rate the descriptors identified in Part I on semantic differential scales. The participants ranged in age from 18 to 27 years $(\underline{M}=18.98)$. Sixty-eight percent were female and $32 \%$ were male. The participants were predominantly $(93 \%)$ European American and they were predominantly (93\%) freshmen and sophomores.

Procedure. Participants were asked to come to one of eight sessions (in a classroom) scheduled at different times to accommodate everyone. Participants were given an informed consent form and instructions (see Appendix C) on how to fill out the semantic differential scales. The participant instructions were adapted from Osgood, Suci, \& Tannenbaum (1957). The participants were then asked for demographic information on gender, undergraduate major, age, race/ethnicity, and college level (see Appendix D). Descriptors identified in Part I were rated using the semantic differential scales shown in Appendix E. The order of the descriptors as well as the order of the semantic differential items were counter-balanced to minimize rating error (from order effect and fatigue). Descriptors that overlapped between victim and alleged perpetrator were only included once. The experience of Osgood et al. led them to conclude that "even the slowest college student subjects can be expected to make judgments at the rate of at least 10 items per minute, and most come closer to 20 items per minute once they get under way. This means that one should allow about 10 to 15 minutes for a 100-item 
test" (p. 80). With 19 descriptors and 11 scales there were 209 items; thus, it was estimated that it would take each student no more than 35 minutes to complete the survey. Upon completion of the survey, participants were given a debriefing statement explaining the purpose of the research (see Appendix F).

Instrument. Osgood's semantic differential (SD) (Osgood et al., 1957) was used to rate each of the 19 descriptors identified in Part I. The SD is not a fixed form for all situations, but rather provides a selection of scales usable for a variety of situations depending upon the purposes of the research. The SD has been used in thousands of empirical studies in a variety of psychological fields (McGuigan, 1995).

As shown in Appendix E, the SD consists of a set of scales, and each scale is comprised of two bipolar adjectives. A respondent rates the word at the top of the page on each 7-point scale. Previous work on the scales identified several factors, three of which were used in the present study: evaluation, potency, and activity. These three factors were chosen because Osgood, Suci, and Tannenbaum (1957) found them to be the major factors, appearing in a "wide variety of judgmental situations, particularly where the sampling of concepts has been broad" (p. 325) and together they account for $50 \%$ of the total variance. While more than three factors contribute to meaningful judgments, these particular three seem to be dominant (pp. 71-72). Other factors identified include stability and receptivity.

Five commonly used scales (good-bad, pretty-ugly, friendly-unfriendly, healthysick, happy-sad) were chosen to measure the evaluation factor which "accounts for approximately half to three-quarters of the extractable variance" (p. 72) and is identified with attitudes, i.e., pro or con, like or dislike. Three commonly used scales (strong-weak, 
big-small, heavy-light) were chosen to measure the potency factor which "typically accounts for approximately half as much variance as the first factor and is concerned with power and the things associated with it, size, weight, toughness, and the like" (pp. 72-73). Three commonly used scales (warm-cold, loud-quiet, moving-still) were chosen to measure the activity factor which accounts for about the same or a little less of the variance than the second factor, and is concerned with quickness, excitement, warmth, agitation, or instrumentality. The more favorable, potent, and/or active a descriptor was rated on the bipolar adjective continuum the higher the score on a 0 to 7 scale.

Analyses. Three $t$ tests were conducted to determine if there were significant differences between the most commonly used descriptors for the victims and the most commonly used descriptors for the alleged perpetrators with regard to the factors of evaluation, potency, and activity. Only one descriptor was common to both groups (victims and alleged perpetrators) and was dropped from the analysis. This descriptor was "young".

\section{Results}

\section{Part I}

The researcher listed and tallied all descriptors for the victims and for the alleged perpetrators. The 10 most commonly used descriptors for victims and the 10 most commonly used descriptors for alleged perpetrators were determined by grouping descriptors with similar meanings, using one of the descriptors to represent the group. (See Appendix G for the words or phrases from which each of the most frequent descriptors was selected.) The high frequency descriptors come from a longer list of descriptors (178 descriptors for the victims and 198 descriptors for the perpetrators). The 
10 most commonly used descriptors are shown in Table 1 with the frequency of their use.

These descriptors were used in Part II of the study where each was rated on the semantic differential by 107 respondents. Only "young" is common to both lists, i.e., was frequently used to describe both victims and alleged perpetrators.

Table 1

$\underline{\text { Most Commonly Used Descriptors for Victims and Alleged Perpetrators }}$

Victim

Descriptors

Frequency

Alleged Perpetrator

Descriptors
Frequency

\begin{tabular}{llll}
\hline Young & 37 & Young & 19 \\
Exemplary & 13 & Brutal & 18 \\
Agitated & 12 & Crude & 16 \\
Naïve & 12 & Tough & 11 \\
Delicate & 10 & Black & 10 \\
Troubled & 9 & Respectful & 9 \\
Lusty & 8 & Sex Crazed & 9 \\
Opportunist & 7 & Confident & 7 \\
Determined & 6 & Affectionate & 6 \\
Helpless & 6 & Beefy & 6 \\
& & & \\
\hline
\end{tabular}

\section{$\underline{\text { Part II }}$}

Each descriptor was rated on 11 semantic differential scales. Five scales measured the evaluation factor (good-bad, pretty-ugly, friendly-unfriendly, healthy-sick, happy-sad); three scales measured the potency factor (strong-weak, big-small, heavylight); and three scales measured the activity factor (warm-cold, loud-quiet, moving-still). From the participants' ratings of the descriptors on these 11 scales of the semantic differential, a score was obtained for each descriptor on the factors of evaluation, 
potency, and activity. The descriptor "young" was left out of the analysis since it was common to both the descriptors used to describe the victims as well as the descriptors used to describe the alleged perpetrators.

Three $t$ tests were performed to determine significant differences between the nine most commonly used descriptors for the victims and the nine most commonly used descriptors for the alleged perpetrators with regard to their judged connotations of evaluation, potency, and activity. All three $t$ tests showed significant differences. The descriptors for the victims were judged to connote less favorability in meaning than the descriptors for the alleged perpetrators $[(\mathrm{M}($ victim $)=4.13, \underline{\mathrm{SD}}=.39 ; \underline{\mathrm{M}}($ perpetrator $)=$ $4.25, \underline{\mathrm{SD}}=.36), \underline{\mathrm{t}}(106)=2.63, \mathrm{p}<.05]$. The descriptors for the victims were judged to connote less potency than the descriptors for the alleged perpetrators $[(\mathrm{M}($ victim $)=3.84$, $\underline{\mathrm{SD}}=.43 ; \underline{\mathrm{M}}($ perpetrator $)=5.34, \underline{\mathrm{SD}}=.47), \underline{\mathrm{t}}(106)=25.61, \underline{\mathrm{p}}<.05]$. The descriptors for the victims were judged to connote less activity than the descriptors for the alleged perpetrators $[(\mathrm{M}($ victim $)=4.06, \underline{\mathrm{SD}}=.34 ; \underline{\mathrm{M}}($ perpetrator $)=4.63, \underline{\mathrm{SD}}=.42), \underline{\mathrm{t}}(106)=$ $12.61, \mathrm{p}<.05]$. Figure 1 presents these findings. 


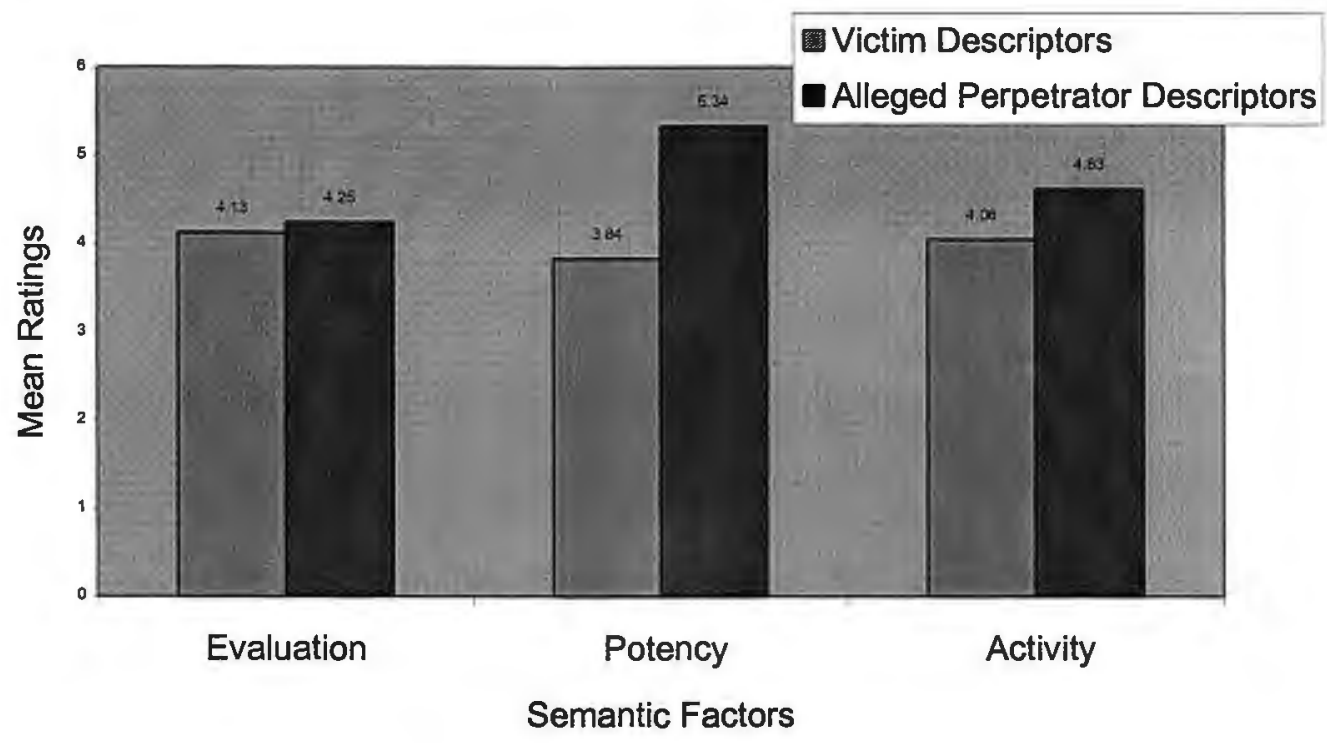

Figure 1. Mean ratings for the victim and alleged perpetrator descriptors on the three semantic factors of evaluation, potency, and activity.

\section{Discussion}

The results of this research support the author's hypotheses and predictions. The descriptors used to describe the victims in articles about rape trials and sexual assault trials in popular U.S. magazines are significantly different from those used to describe the alleged perpetrators on three semantic factors: evaluation, potency, and activity. Words used to describe the victims were judged to connote less favorability, less potency, and less activity than those used to describe the alleged perpetrators. These differences were found through three layers of discovery: first, the journalists chose which descriptors to use; then the researcher identified the words within the articles; and then the participants judged the words. Despite this indirect measure, significant differences were found between the connotative meanings of victim and alleged perpetrator descriptions. 
Some limitations in the present study should be noted. First, interpreting and generalizing from these results must be tempered by noting the non-randomness of the participants who responded to the descriptors. In addition, because the articles sampled were taken from popular magazines, they were about trials that were highly publicized (e.g., the Mike Tyson trial). Future research might well focus on press reports in newspapers about local trials that receive less national coverage. The conventions of writing are different in magazines and newspapers; in the latter, there is less acceptance of opinion than is found in magazines. Furthermore, the sample of 44 articles analyzed here were about only 14 different rape and sexual assault trials, 21 articles on the Mike Tyson trial and 6 on the Central Park Jogger case. These articles, however, were read across the United States in popular news magazines. Their influence is potentially greater since they reach a larger number of people and a more diverse group of people.

Some of the frequently mentioned descriptors were found in quotations. While the journalist chose the quote, future studies may want to separate and consider two groups of descriptors (those taken from a quote and those not taken from a quote). This strategy was not followed in the present study because the connotative meanings of only the 20 most frequently used descriptors were examined and their frequency was too small to separate descriptors on the basis of whether or not they had appeared in quotes. An important consideration in understanding the significance of the findings in this study is that the quotes used were, in fact, chosen by the journalist. The focus of this study was on the use of words that contribute to the perpetuation of rape myths, with no assignment of blame for words chosen by journalist. Journalists may be using these terms carelessly because they are so commonplace. They may be unaware of their adverse influence and 
their potential for the perpetuation of rape myths. These findings should be of interest to journalists in their pursuit of unbiased/objective reporting.

The present study was exploratory. It differs from past research in terms of its methodology and is, to the best of the researcher's knowledge, the first study to use a quantitative approach to evaluate the words that journalists use in news stories about rape. Nevertheless, these results are consistent with other research (e.g., Benedict, 1992; Meyers, 1994), and suggest a bias in the way in which the print media portray rape and sexual assault trials.

The descriptors identified in the news articles were words used to describe the victims and alleged perpetrators. They included adjectives, adverbs, and words used as adjectives and adverbs used in connection with victims and alleged perpetrators. The descriptors that the participants rated on Osgood's semantic differential, those that appeared most frequently in the news stories, were presented simply as words without contextual reference, which is standard practice when using the semantic differential to identify connotative meaning. Some have argued, however, that connotative meaning should be derived from context, i.e., that no word has connotative meaning by itself. Future research might want to place the words in context and see if men and women rate words used to describe victims and perpetrators differently.

The English language is not gender neutral. Different trait terms are frequently used to describe women and men. Supporting the validity of the present findings is that substantially more desirable trait terms are generally used for women and substantially more undesirable trait terms are used for men (Corbitt, Sankis, \& Widiger, 1999). That the present study found that words used to describe alleged perpetrators of rape connoted 
more favorability (on the scales used here) than the words to describe rape victims, is in sharp contrast to the larger set of desirable trait terms available to journalists to describe women in general.

The words used to describe the victims connote a negative set of beliefs and, thus, perpetuate rape myths. The rape myths "rape is sex", "she provoked it" and "only loose women are raped" are supported by victim descriptors such as: lusty, consenting, willing partner, and eager. The rape myth "the assailant is motivated by lust" is supported by alleged perpetrator descriptors such as: sex crazed, sexual predator, and sexually ravenous. The myth "women cry rape for revenge" is supported by victim descriptors such as: opportunist, gold digger, wily, and compelling desire for money. The reason the descriptor "Black" came up so frequently was because so many articles dealt with the Tyson trial. However, of particular interest, is that, while both the victim and alleged perpetrator in the Tyson trial were Black, "Black" was a commonly used descriptor only for the alleged perpetrators and not the victims. This tends to support the myth "the assailant is usually Black".

It is reasonable to assume that the descriptors used by journalists affect the way in which victims and perpetrators are perceived by their readers. If we judge a victim to be unworthy, weak, and inactive, then we may excuse sexual assault and rape. The use of words that connote less favorability, less potency, and less activity tends to perpetuate rape myths. As in many rape myths the language used can blame the victim for her assault by accusing her of inviting or deserving the attack. All this denies the reality of many actual rapes, reduces a reader's capacity to empathize with the victim, distances us from her, and diminishes the atrocity of the crime. 


\section{References}

Benedict, H. (1992). Virgin or vamp: How the press covers sex crimes. New York: Oxford University Press.

Brinston, S. L. (1992). The use and opposition of rape myths in prime-time television dramas. Sex Roles, 27(7/8), 359-375.

Brownmiller, S. (1975). Against our will: Men, women and rape. New York: Simon and Schuster.

Burt, M. R. (1980). Cultural myths and supports for rape. Journal of Personality and Social Psychology, 38, (2), 217-230.

Burt, M. R. and Albin, R. S. (1981). Rape myths, rape definitions, and probability of conviction. Journal of Applied Social Psychology, 11, (3), 212-230.

Cline, V. R., Croft, R. G., \& Carrier, S. (1973). Desensitization of children to television violence. Journal of Personality and Social Psychology, 27(3), 360-365.

Corbitt, E. M., Sankis, L. M., \&Widiger, T. A. (1999). Gender bias in the English language? Journal of Personality and Social Psychology, 77, (6), 1289-1295.

Donat, P. and D'Emilio, J. (1992). A feminist redefinition of rape and sexual assault: Historical foundations and change. Journal of Social Issues, 48 (1), 9-22.

Holzman, C. G. (1994). Multicultural perspectives on counseling survivors of rape. Journal of Social Distress and the Homeless, 3, (1), 81-97.

Kielwasser, A. P. and Wolf, M. A. (1994). Silence, difference, and annihilation:

Understanding the impact of mediated heterosexism on high school students. The High School Journal, 77, 58-79. 
Koss, M. P., Gidycz, C. J., \& Wisniewski, N. (1987). The scope of rape: Incidence and prevalence of sexual aggression and victimization in a national sample of higher education students. Journal of Consulting and Clinical Psychology, 55, 162-170.

Koss, M. P., \& Burkhart, B. R. (1989). A conceptual analysis of rape victimization: Long-term effects and implications for treatment. Psychology of Women's Quarterly, 13 (1), 27-40.

Koss, M. P. (1992). The underdetection of rape: Methodological choices influence incidence estimates. Journal of Social Issues, 48 (1), 61-75.

Linz, D. G., Donnerstein, E., \& Penrod, S. (1984). The effects of multiple exposures to filmed violence against women. Journal of Communication, 34, 130-147.

Linz, D. G., Donnerstein, E., \& Penrod, S. (1988). Effects of long-term exposure to violent and sexually degrading depictions of women. Journal of Personality and Social Psychology, 55 (5), 758-768.

Lott, B. (1994). Women's lives: Themes and variations in gender learning (2nd Ed.). Pacific Grove, CA: Brooks/Cole.

McGuigan, J. E. (1995). Charles Eggerton Osgood (1916-1991). American Psychologist, 50 (3), 173-174.

Meyers, M. (1994). News of battering. Journal of Communication, 44, (2), 47-63.

Mullin, C. R., \& Linz, D. (1995). Desensitization and resensitization to violence against women: Effects of exposure to sexually violent films on judgments of domestic violence victims. Journal of Personality and Social Psychology, 69, 449-459.

Osgood, C.E., Suci, G.J., \& Tannenbaum, P.H. (1957). The measurement of meaning. Urbana, Illinois: University of Illinois Press 
Reilly, M. E., Lott, B., Caldwell, D., and DeLuca, L. (1992). Tolerance for sexual harassment related to self-reported sexual victimization. Gender \& Society, 6, $122-138$

Renzetti, Claire M. \& Curran, Daniel J. (1999). The great communicators: Language and the media. In Women, Men, and Society (4th ed.). (pp. 119-148). Boston: Allyn and Bacon.

Sanday, P. R. (1981). The sociocultural context of rape: A cross-cultural study. Journal of Social Issues, 37, 5-27.

Sanday, P. R. (1990). Fraternity gang rape: Sex, brotherhood, and privilege on campus. New York and London: New York University Press.

Soothill, K. (1991). The changing face of rape? British Journal of Criminology, 31, (4), 383-392.

SRDS Consumer Magazine Advertising Source, 81, (7), p. A40.

U.S. Department of Justice. Bureau of Justice Statistics [On-line]. Available: http://www.ojp.usdoj.gov/bjs/

Weis \& Borges,(1973). Victimology and rape: The case of the legitimate victim. Issues in criminology, 8, (2); 71-115.

White, J. and Sorenson, S. (1992). A sociocultural view of sexual assault: From discrepancy to diversity. Journal of Social Issues, 48, (1) 187-195.

Wyatt, G. E. (1992). The sociocultural context of African American and White American women's rape. Journal of Social Issues, 48, (1), 77-91. 


\section{Appendix A}

Articles (listed by date, starting with most recent)

- Trials and errors. (last-season difficulties of Cleveland pitcher J. Mesa). Author: Crothers, Tim Source: Sports Illustrated Date: Jan 19, 1998

- $\mathrm{Oh}$, no! for the Yes man. (trial destroys career of sportscaster M. Albert). Author: Wulf, Steve Source: Time Date: Oct 06, 1997

- The fugitive goes on trial. (accused rapist A. Kelly stands trial in Darien, Conn.). Author: Gleick, Elizabeth Source: Time Date: Nov 04, 1996

- Judgment days. (accused rapist A. Kelly faces trial in Connecticut). Author: Hewitt, Bill Source: People Weekly Date: Nov 041996

- Wife of alleged rapist apologizes to Japanese victim's parents. (Wife of serviceman R. Harp). Author: Anonymous Source: Jet Date: Dec 25, 1995

- Jury convicts Chicago congressman Mel Reynolds on four counts in sex abuse trial. Author: Anonymous Source: Jet Date: Sept 11, 1995

- An affair to forget. (M. Reynolds convicted after affair with B. Heard). Author: Sanz, Cynthia Source: People Weekly Date: Sept 04, 1995

- A voice crying out. (K. Absalon wins new rape trial). Author: Hewitt, Bill; Eftimiades, Maria Source: People Weekly Date: Aug 21, 1995

- Tupac Shakur apologizes to woman he sexually abused; is sentenced to four years in prison. Author: Anonymous Source: Jet Date: Feb 27, 1995

- Double trouble for 2pac. (T. Shakur). Author: Hamilton, Kendall Source: Newsweek Date: Dec 12, 1994

- Judge ordered to review background of Tyson's accuser. Author: Anonymous Source: Jet Date: Apr 25, 1994

- U.S. Supreme Court ruling no surprise to Tyson, close friend says. Author: Anonymous Source: Jet Date: Mar 21, 1994

- Indiana court upholds Tyson rape conviction. Author: Anonymous Source: Jet Date: Aug 23, 1993 
- Verdict after a day of horror. (rape of retarded girl in Glen Ridge, N.J.). Author: Kantrowitz, Barbara Source: Newsweek Date: Mar 29, 1993

- Irresponsible acts. (verdict in Glen Ridge, N.J. rape case). Author: Anonymous Source: Newsweek Date: Mar 29, 1993

- Desiree Washington. (brought charges against M. Tyson). Author: Anonymous Source: People Weekly Date: Dec 28, 1992

- Desiree Washington charges Tyson gave her VD; Case could aid boxer's defense. Author: Anonymous Source: Jet Date: Dec 07, 1992

- Tyson's lawyer raises perjury issue to gain jail release, new trial. Author: Anonymous Source: Jet Date: Jul 13, 1992

- Tyson's bail denied, must remain in jail. Author: Anonymous Source: Jet Date: Apr 20, 1992

- Mike Tyson sentenced to six years, appeal filed immediately. Author: Anonymous Source: Jet Date: Apr 13, 1992

- National Petitions seek leniency for Mike Tyson. Author: Anonymous Source: Jet Date: Mar 30, 1992

- Rape charges dropped against Run DMC member. (J. Simmons). Author: Anonymous Source: Jet Date: Mar 09, 1992

- Juror in Tyson rape case gives behind-the-scenes view of verdict. (cover story) Author: Moore, Trudy S Source: Jet Date: Mar 02, 1992

- The bad and the beautiful. Author: Corliss, Richard Source: Time Date: Feb 24, 1992

- A damnable defense. (racial stereotypes employed at M. Tyson trial). Author: Steptoe, Sonja Source: Sports Illustrated Date: Feb 24, 1992

- Mike Tyson convicted of raping teen beauty, faces 60 years in jail. Author: Anonymous Source: Jet Date: Feb 24, 1992

- Judgment day. (M. Tyson convicted of rape charges brought by Miss Black America contestant D. Washington: cover story). Author: Treen, Joe; Shaw, Bill Source: People Weekly Date: Feb 24, 1992 
- A crushing verdict. (M. Tyson found guilty: cover story). Author: Nack, William Source: Sports Illustrated Date: Feb 17, 1992

- She never told me to stop. (M. Tyson trial). Author: Anonymous Source: Newsweek Date: Feb 17, 1992

- A gruesome account. (M. Tyson trial). Author: Nack, William Source: Sports Illustrated Date: Feb 10, 1992

- In judgment of Iron Mike. (M. Tyson). Author: Corliss, Richard Source: Time Date: Feb 10, 1992

- Lawyers to their corners. (M. Tyson to go on trial for allegedly raping a Black Miss America contestant). Author: Callahan, Tom Source: U.S. News and World Report Date: Feb 03, 1992

- On Trial. (M. Tyson). Author: Nack, William Source: Sports Illustrated Date: Jan 20, 1992

- He started laughing like it was a game. (M. Tyson trial). Author: Barrett, Todd Source: Newsweek Date: Feb 10, 1992

- Rangel demands fed prosecute in rape case. (St. John's University students). Author: Anonymous Source: Jet Date: Aug 19, 1991

- Acquittal and injustice in Queens. (trial of St John's University students). Author: Leo, John Source:_U.S. News and World Report Date: Aug 12, 1991

- The six faces of Sarah bear witness to a sexual assault. (M. Peterson on trial for raping a woman with multiple personality disorder). Author: Grogan, David Source: People Weekly Date: Nov 26, 1990

- The 21 faces of Sarah. (M. Peterson on trial for raping a woman with multiple personality disorder). Author: Smolowe, Jill Source: Time Date: Nov 12, 1990

- As the Central Park jogger struggles to heal, three attackers hear the bell toll for them. Author: Podolsky, J. D.; Balfour, Victoria; Eftimiades, Maria Source: People Weekly Date: Sept 03, 1990

- Guilty, guilty, guilty. Author: Trippett, Frank Source: Time Date: Aug 27, 1990

- Judgment for the 'wilders'. Author: Turque, Bill Source: Newsweek Date: Aug 27,1990 
- Justice in black and white. (Central Park jogger trial). Author: Turque, Bill Source: Newsweek Date: Aug 13, 1990

- Risen from near death, the Central Park jogger makes her day in court one to remember. Author: Kunen, James S. Source: People Weekly Date: Jul 30, 1990

- Still shocking after a year. Author: Kantrowitz, Barbara Source: Newsweek Date: Jul 23, 1990 
Appendix B

Title of Article:

Descriptor Tally Form

Author:

Date:

Magazine:

Brief Summary of Article:

Descriptors include adjectives, adverbs, and words used as adjectives or adverbs. Tally marks indicate the number of times each descriptor appears in the article associated with the victim(s) or alleged perpetrator(s). Quotation marks instead of a tally indicate that the descriptor comes from a quote (e.g., 1. sexy

Victim

$\underline{\text { Descriptor Tally }}$

1.

2.

3.

4.

5.
Alleged perpetrator

Descriptor Tally

$\underline{\text { Total }}$

1.

2.

3.

4.

5. 
6.

7.

8.

9.

10.

11.

12.

13.

14.

15.

16.

17.

18.

19.

20.

21.

22.

23.

24.

25.

26.

27.

28.

29.

30.

31.
6.

7.

8.

9.

10.

11.

12.

13.

14.

15.

16.

17.

18.

19.

20.

21.

22.

23.

24.

25. 26. 27. 28. 29. 30. 31. 


\author{
Appendix C \\ Informed Consent and Instructions for Semantic Differential Scale
}

Informed Consent

\title{
TEAR OFF AND KEEP THIS PAGE FOR YOURSELF
}

You have volunteered to participate in a research study looking at the meanings of words. The researcher will explain the project to you in detail. You should feel free to ask questions. If you have more questions later, Laura Chorbajian, the person mainly responsible for this study, will discuss them with you and can be reached at (401) 8744248. You must be at least 18 years old to be in this research project.

Description of the project:

You have been asked to take part in a study looking at the meanings of words.

What will be done:

If you decide to take part in this study, you will be asked to rate the meanings of no more than 30 words by judging them on a series of scales. This should take approximately $35-$ 50 minutes.

Risks or discomfort:

There are no known risks or discomfort to participating in this study.

Benefits of this study:

Although there will be no direct benefit to you for taking part in this study, the researcher may learn more about the meanings of words.

Confidentiality:

All information obtained from this study is anonymous. None of the information will identify you by name.

Decision to quit at any time:

The decision to participate in this research study is voluntary. You do not have to participate in this study and should you decide to take part in this study, you may quit at any time. 
Your rights:

If you have any questions or concerns about this research project, you may discuss them with Laura Chorbajian, (401) 874-4248, anonymously if you choose. In addition, you may contact the person supervising her research, Dr. Bernice Lott, at the University of Rhode Island's Psychology Department at (401) 874-4248, or you may contact the office of the Vice Provost for Graduate Studies, Research and Outreach, 70 Lower College Road, Suite 2, University of Rhode Island, Kingston, Rhode Island, telephone: (401) 8742635

You are at least 18 years old. You have read the consent form and your questions have been answered. The completion of the survey and handing it in to the researcher or research assistant shall mean that you have read this consent form and have agreed to participate in this study.

Thank you, Laura Chorbajian 


\section{Instructions}

The purpose of this study is to measure the meanings of certain words by having people judge them against a series of 11 descriptive scales. On each page of this booklet you will find a different word to be judged and beneath it a set of scales. You are to rate the word on each of these scales in order. Here is how you are to use these scales:

If you feel that the word at the top of the page, for example "honest", is very closely related to one end of the scale, you should place an $\mathrm{X}$ as follows:

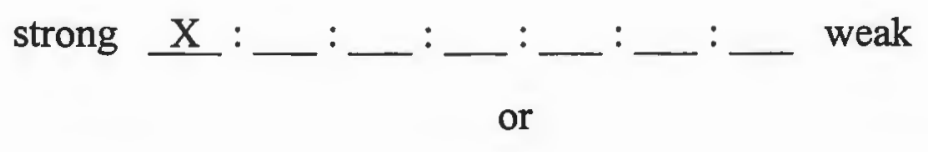

strong __ $:$ _ _ $:$ _

If you feel that the word at the top of the page is closely related to one end of the scale you should place an $\mathrm{X}$ as follows:
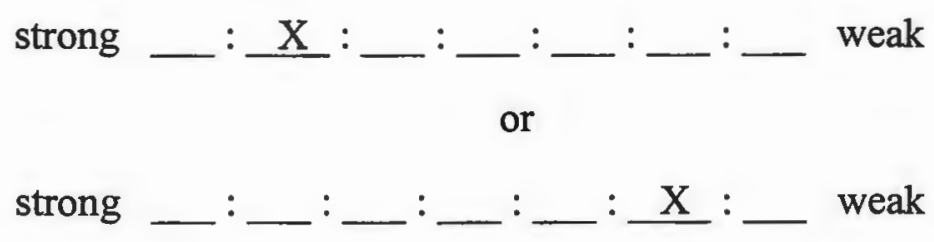

If you feel that the word at the top of the page is only slightly related to one end of the scale you should place an $\mathrm{X}$ as follows:

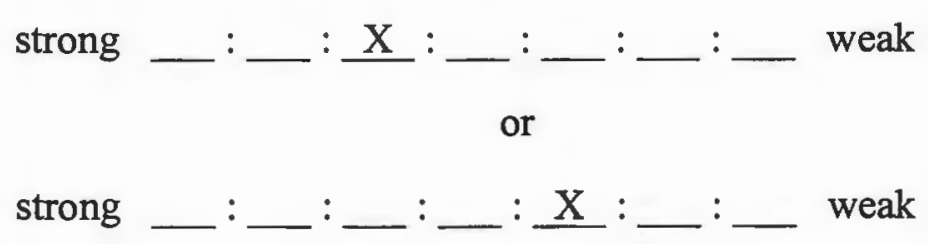

The direction toward which you place your $\mathrm{X}$, of course, depends upon which of the two ends of the scale seem most characteristic of the word you're judging.

If you consider the word to be neutral on the scale or completely irrelevant, then you should place your $\mathrm{X}$ in the middle space:

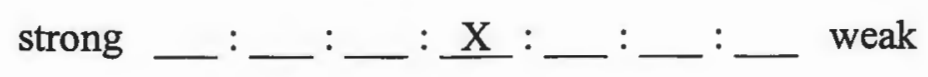

\section{IMPORTANT:}

- Place your X's in the middle of spaces, not on the boundaries: 


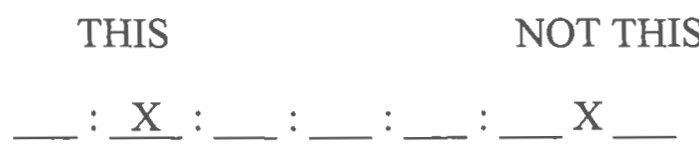

- Be sure you check every scale for every word - do not omit any:

- Never put more than one $\mathrm{X}$ on a single scale.

Sometimes you may feel as though you've seen the same item before. This will not be the case, so do not look back and forth through the items. Do not try to remember how you checked similar items earlier. Make each item a separate and independent judgment. Work at a very high speed through this test. Do not worry or puzzle over individual items. It is your first impressions or immediate feelings about the words that we want. On the other hand, please do not be careless, because we want your true impressions. 


\section{Appendix D \\ Demographic Information}

Would you be good enough to answer a few questions about yourself:

What is your age?

What is your gender?

What is your undergraduate major?

What is your race/ethnicity?

Are you a freshman, sophomore, junior, or senior? (Circle one) 
Appendix E

Semantic Differential Scales

[Descriptor]

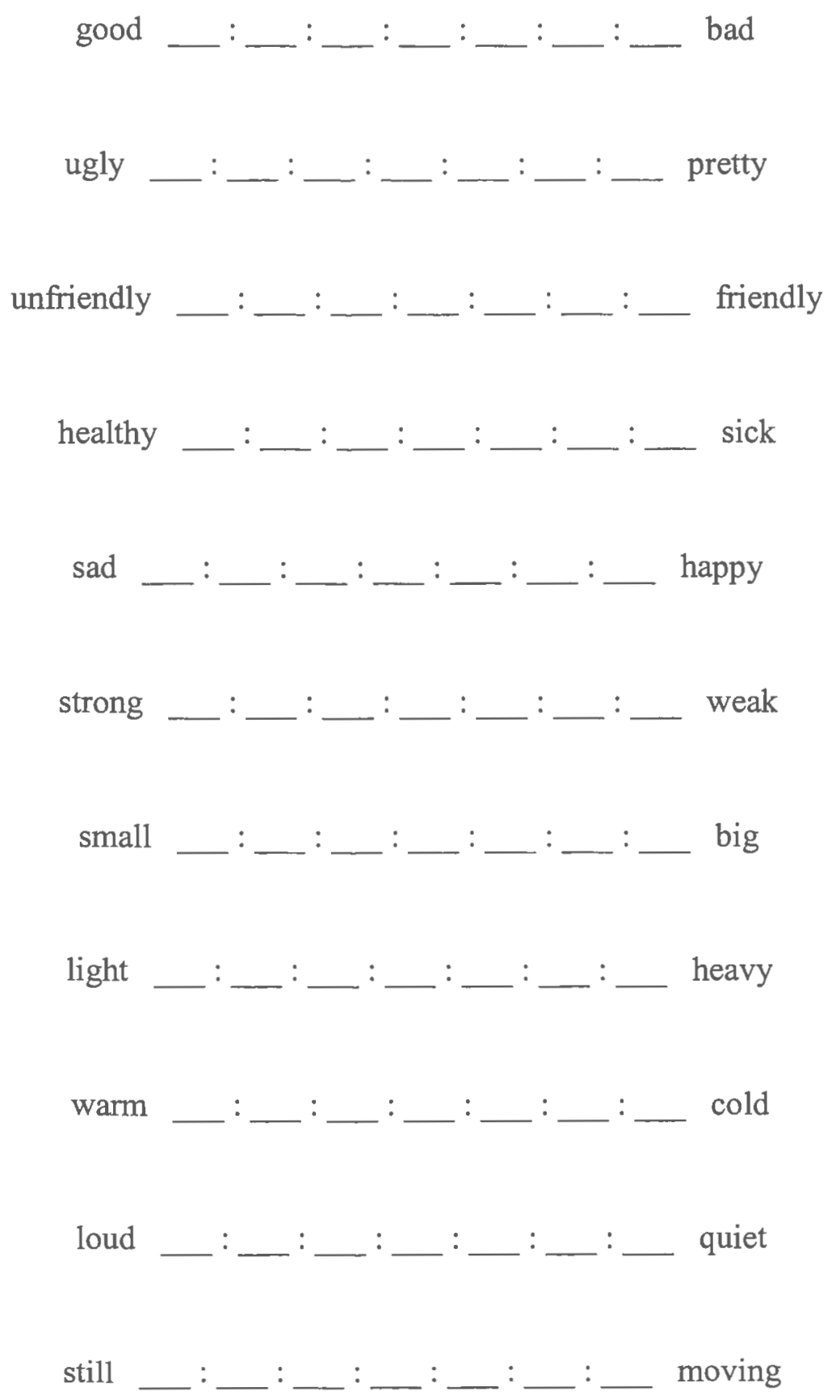




\section{Appendix F}

Debriefing Statement:

\section{Dear Participant,}

We want you to know that the words you just responded to came from a review of news articles in magazines on rape and sexual assault trials. This research is designed to see if there are differences in connotative meaning between the words used to describe victims and those used to describe alleged perpetrators in media reports of these trials.

Thank you for your participation. If you have any questions, you can leave a message for me with my major professor, Bernice Lott, who can be reached at 874-4248.

\section{PLEASE DO NOT DISCUSS THIS SURVEY WITH YOUR CLASSMATES. THANK YOU!}


Appendix G

\section{Most Frequently Used Victim Descriptors}

\section{Young}

Looks younger

Teenager

Baby of group

Exemplary

Model citizen

Model student

Most outstanding sophomore

Honor student

Scholarship student

National junior honor society

Neither drank nor smoked

Girl next door

All American girl

Good kid

\section{Agitated}

Distraught

Hysterical

Shocked

Nervous

Shaken

Upset

Anguished

Devastated

Frenzied

\section{Naïve}

Innocent child

Pure heart

Real sweet

Stary eyed

Trusting

Wide-eyed

Without guile
Petite

Diminutive

Slender

Small

Tiny

\section{Troubled}

Anxious

Apprehensive

Depressed

Mood swings

Unable to hold down job

Unsteady

\section{Lusty}

Asking for trouble

Consenting

Willing

Willing partner

Eager

Knew exactly

\section{Opportunist}

Gold diggers

Compelling desire for money

Wily

\section{Determined}

Inner strength

Spunky

Unwavering

Has will

\section{Helpless}

Demure

Vulnerable

Not streetwise

Open

\section{Delicate}


Most Frequently Used Alleged Perpetrator Descriptors

\section{Young}

\section{Brutal}

Dangerous

Conqueror

Hunter

Savage

Beyond evil

Black heart

Horrific

Man-beast-machine

\section{Crude}

Lewd

Foul mouthed

Offensive

Vulgar

Course

Surly

\section{Tough \\ Violent \\ Warrior \\ Thug \\ Threatener \\ Street creep \\ Purged of moral compunctions \\ Baddest}

\section{Black}

African-American

\section{Respectful}

Quiet

Nice boy

Like boy next door

Soft

Trusting

Well spoken

Naïve

\section{Sex Crazed}

Sexual predator

Sexually ravenous

Pincher

Past difficulties with women

\section{Confident}

Calm

Composed

Relaxed

Not angry

Not defiant

\section{Affectionate \\ Gentle \\ Loving \\ Lover \\ Hints of heart}

\section{Beefy}

Hulking

Imposing

Broad neck

Uncomfortable in the chair

Caged in his chair 


\section{Bibliography}

Benedict, H. (1992). Virgin or vamp: How the press covers sex crimes. New York: Oxford University Press.

Brinston, S. L. (1992). The use and opposition of rape myths in prime-time television dramas. Sex Roles, 27(7/8), 359-375.

Brownmiller, S. (1975). Against our will: Men, women and rape. New York: Simon and Schuster.

Burt, M. R. (1980). Cultural myths and supports for rape. Journal of Personality and Social Psychology, 38, (2), 217-230.

Burt, M. R. and Albin, R. S. (1981). Rape myths, rape definitions, and probability of conviction. Journal of Applied Social Psychology, 11, (3), 212-230.

Cline, V. R., Croft, R. G., \& Carrier, S. (1973). Desensitization of children to television violence. Journal of Personality and Social Psychology, 27(3), 360-365.

Corbitt, E. M., Sankis, L. M., \&Widiger, T. A. (1999). Gender bias in the English language? Journal of Personality and Social Psychology, 77, (6), 1289-1295.

Donat, P. and D'Emilio, J. (1992). A feminist redefinition of rape and sexual assault: Historical foundations and change. Journal of Social Issues, 48 (1), 9-22.

Holzman, C. G. (1994). Multicultural perspectives on counseling survivors of rape. Journal of Social Distress and the Homeless, 3, (1), 81-97.

Kielwasser, A. P. and Wolf, M. A. (1994). Silence, difference, and annihilation:

Understanding the impact of mediated heterosexism on high school students. The High School Journal, 77, 58-79. 
Koss, M. P., Gidycz, C. J., \& Wisniewski, N. (1987). The scope of rape: Incidence and prevalence of sexual aggression and victimization in a national sample of higher education students. Journal of Consulting and Clinical Psychology, 55, 162-170.

Koss, M. P., \& Burkhart, B. R. (1989). A conceptual analysis of rape victimization: Long-term effects and implications for treatment. Psychology of Women's Quarterly, 13 (1), 27-40.

Koss, M. P. (1992). The underdetection of rape: Methodological choices influence incidence estimates. Journal of Social Issues, 48 (1), 61-75.

Linz, D. G., Donnerstein, E., \& Penrod, S. (1984). The effects of multiple exposures to filmed violence against women. Journal of Communication, 34, 130-147.

Linz, D. G., Donnerstein, E., \& Penrod, S. (1988). Effects of long-term exposure to violent and sexually degrading depictions of women. Journal of Personality and Social Psychology, 55 (5), 758-768.

Lott, B. (1994). Women's lives: Themes and variations in gender learning (2nd Ed.). Pacific Grove, CA: Brooks/Cole.

McGuigan, J. E. (1995). Charles Eggerton Osgood (1916-1991). American Psychologist, 50 (3), 173-174.

Meyers, M. (1994). News of battering. Journal of Communication, 44, (2), 47-63.

Mullin, C. R., \& Linz, D. (1995). Desensitization and resensitization to violence against women: Effects of exposure to sexually violent films on judgments of domestic violence victims. Journal of Personality and Social Psychology, 69, 449-459.

Osgood, C.E., Suci, G.J., \& Tannenbaum, P.H. (1957). The measurement of meaning. Urbana, Illinois: University of Illinois Press 
Reilly, M. E., Lott, B., Caldwell, D., and DeLuca, L. (1992). Tolerance for sexual harassment related to self-reported sexual victimization. Gender \& Society, 6, $122-138$.

Renzetti, Claire M. \& Curran, Daniel J. (1999). The great communicators: Language and the media. In Women, Men, and Society ( $4^{\text {th }}$ ed.). (pp. 119-148). Boston: Allyn and Bacon.

Sanday, P. R. (1981). The sociocultural context of rape: A cross-cultural study. Journal of Social Issues, 37, 5-27.

Sanday, P. R. (1990). Fraternity gang rape: Sex, brotherhood, and privilege on campus. New York and London: New York University Press.

Soothill, K. (1991). The changing face of rape? British Journal of Criminology, 31, (4), 383-392.

SRDS Consumer Magazine Advertising Source, 81, (7), p. A40.

U.S. Department of Justice. Bureau of Justice Statistics [On-line]. Available: http://www.ojp.usdoj.gov/bjs/

Weis \& Borges,(1973). Victimology and rape: The case of the legitimate victim. Issues in criminology, 8, (2); 71-115.

White, J. and Sorenson, S. (1992). A sociocultural view of sexual assault: From discrepancy to diversity. Journal of Social Issues, 48, (1) 187-195.

Wyatt, G. E. (1992). The sociocultural context of African American and White American women's rape. Journal of Social Issues, 48, (1), 77-91. 